\title{
Moral Conscience and Psychological Conflict in Shakespeare's Character Angelo from the Play Measure for Measure
}

\author{
Giuseppe Giordano \\ Department of Mental Health, Azienda Sanitaria Locale CN2, Alba-Bra, CN, Italy \\ Email: giugiordano1969@alice.it
}

How to cite this paper: Giordano, G. (2021). Moral Conscience and Psychological Conflict in Shakespeare's Character Angelo from the Play Measure for Measure. Advances in Literary Study, 9, 224-229. https://doi.org/10.4236/als.2021.94023

Received: September 29, 2021

Accepted: October 26, 2021

Published: October 29, 2021

Copyright $\odot 2021$ by author(s) and Scientific Research Publishing Inc. This work is licensed under the Creative Commons Attribution International License (CC BY 4.0).

http://creativecommons.org/licenses/by/4.0/

\begin{abstract}
Measure for Measure is a play by William Shakespeare that represents moral issues concerning corruption, virtue, justice and purity. A prominent character of the play, Angelo, holds the position of Deputy and representative of the law but his conscience is tormented by a psychological conflict around the desire to bribe a young and innocent lady, Isabella, for his own interest and pleasure. The aim of this paper is to analyze the mental distress of Angelo's moral conscience in relation to Sigmund Freud's models of functioning of the human mind. An extract from the play has been chosen for this investigation, which is the character's monologue in Act 2, scene 2, lines 167-191 since it clearly represents the relationship between moral reflection and the psychological effects on the psyche.
\end{abstract}

\section{Keywords}

Shakespeare, Measure for Measure, Morality, Freud, Psychological Conflict

\section{Introduction}

The Shakespearean play Measure for Measure was first performed in 1604 as a comedy representing complex issues related to morality. However, it has frequently been the object of debate for what concerns its genre. Some scholars believe that the play is to be considered a tragedy because of its dramatic tone while other critics consider the piece rather a "problem" comedy because of its exploration of moral issues in a comic form. The debate and ambiguity about the genre of the play are reflected in the speeches of the different characters and, in particular, of Angelo who is in charge to condemn the misconduct of a young gentleman, Claudio, accused of adultery. Angelo is a deputy and thus a figure representing authority and law, but he is also condemnable for his dishonest be- 
haviour. Hence, the questions raised by Shakespeare in the play refer to what is ethically right or wrong, to moral responsibility, human fragility, and personal rectitude. Moral conscience can be considered as the knowledge of what is good or bad, right or wrong, as well as the realization that if a person acts in an honest and virtuous way, a condition of mental tranquility and inner peace can be achieved. Moreover, it is a matter of personal decision whether an individual chooses to behave in a morally correct or unacceptable way. Such a decision can be driven by a conscious intention as well as by the human instincts of the preservation of species (Vithoulkas \& Muresanu, 2014). The aim of this article is to investigate the psychological conflict of Angelo around moral issues, in relation to Sigmund Freud's structural or tripartite model of the mind that divides the psyche into three parts: Ego, Id and Super-Ego (Freud, 1923). The Ego is the part that is related to perception, emotions and will and is primary conscious, the Id represents the instinctual life, that is sexual desires and aggressive drives, and is entirely unconscious whereas the Super-Ego is the part that concerns morality, values and principles of conduct and is mainly unconscious. Freud's structural model is an evolution of his previous topographical theorization that describes three levels of the mind which are the conscious mind, the preconscious and the unconscious (Freud, 1915). See also Figure 1 for a graphic illustration of Freud's model of the human mind. The investigation is related essentially to the conflict among Ego, Id and Super-Ego around the moral considerations that emerge from Angelo's monologue in the play Measure for Measure, 2.2., 167-191, (Greenblatt, 1997) along with an explanation of the literary devices used by the author to underline the problem of the moral conscience of his character.

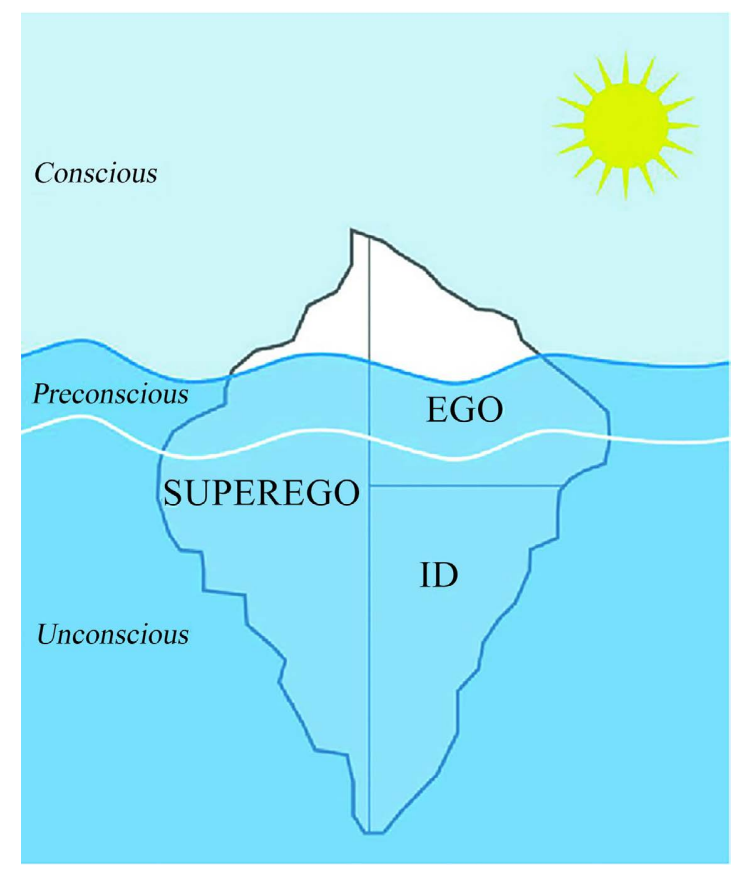

Figure 1. Illustration of the iceberg metaphor commonly used for Freud's model. From https://www.researchgate.net/figure/Illustration-of-the-iceberg-metaphor-commonly-use d-for-Freuds-model-Public-domain_fig2_335868841. 


\section{Discussion}

Angelo's soliloquy is a speech of twenty-five lines from Act 2 scene 2 that follows immediately the dialogue between this character and Isabella when the latter exits the scene with Lucio and Provost. Isabella is an aspiring nun, Claudio's sister, and is depicted as a symbol of high moral values, especially of integrity and purity. Their dialogue consists mainly of a debate about the strict application of law by the Deputy, Isabella's request of mercy and the idea of having sex with her in favour of her brother's release.

In his article on the character of Angelo (Dodds, 1946), the author provides relevant insights into the figure and role of the Deputy in the play. Firstly, it is difficult to well comprehend the true nature of Angelo since he is depicted as a moralist and honest person who is troubled by sexual drives, but his interior conflict does not resemble the profound sufferings of the characters of Shakespeare's tragedies, like Macbeth for example. Secondly, as a representative of justice he may be ideologically infallible and correct but his role as delegate of moral rules, and of their application, is in clear contrast with his personal failure to respect ethical standards and to reflect properly on his sinful intentions. Thirdly, there is a problem of conscience in the character's mind, who deliberately assumes that passions and human instincts may justify misbehavior but, at the same time, is undecided as in Act 2, scene 4, lines 57-59 in which he interacts with Isabella, the presumed reason of his temptation: "...Our compelled sins Stand more for number than for account. ...Nay, I'll not warrant that..." Lastly, in matters of sins and human failure, the question of religion and divine justice is of extreme relevance in this play. In fact, Dodds points out that the problem of mercy as a Christian ideal does not fit well with the representation of Angelo as a person who is aware of the immorality of his own shameful conclusions.

Angelo's speech starts with the character asking himself whether the thoughts that are crossing his mind and the plans that he is making belong to his intentionality or are the responsibility of the virtuous lady as expressed in line 167: "What's this? What's this? Is this her fault or mine?" This is an example of rhetorical question since it puts emphasis on an important issue of the play, morality, and serves the purpose of drawing the audience's attention. Moreover, the repetition of the first question twice likely gives more stress to the thoughtful experience of the speaker. According to Freud's tripartite model, the conflict here arises from the Ego who is trying to defend himself from the pressures of the Id, represented by the sexual desires towards Isabella, and the disapproval of the Super-Ego, depicted by the word "fault". In fact, Angelo's attempt is to attribute the responsibility of his fantasies to the lady as an expression of the Ego's defense in a moment of intense doubtfulness ("who sins most, ha?").

In line 168, there is another example of language used to create literary effect which concerns the question of who is more responsible for the enticement: Isabella, the pious and god-fearing character, or Angelo, the emblem of justice and impartiality. As anticipated above, the first two lines of the soliloquy express the 
doubts that torment the conscience of the character who is thus represented in his true nature, a person made of instincts and urges in clear contrast with the social role of officer of justice. Angelo's interior dialogue moves then, in lines $169-172$, to the self-awareness of his culpability, the realisation that he is a liar and that he is rather a corrupted and nasty person ("but it is I"). Interesting here is the use that Shakespeare makes of similes in line 171 to create the effect of immorality: "Do as the carrion does, not as the flower." Flowers are symbols of innocence, purity and usually have a pleasant smell while a carrion is lifeless, empty inside and even worse, it stinks. Indeed, an immoral person can feel and be considered torpid and filthy. The conflict between the three parts of the psyche is apparently mitigating here as Angelo is blaming himself and not another person, which psychologically means that the Ego is becoming aware of the sexual impulses emerging from the Id and, consequently, the Super-Ego is turning out to be less oppressive in this regard.

Angelo's sequence of thoughts proceeds in lines 172-176 with a rhetorical question about the fact that men can be easily seduced by women's humble conduct rather than by their delicacy. According to Dodds, these lines represent the character's effort to underline a universal truth about women's attitude, which is again in contrast with the speaker's lack of humility and correctness in dealing with Isabella's life. The "waste ground", in line 174, is likely a metaphor to express the desolation of a human's inner life and, moreover, a condition that refers also to other individuals since the writer refers to a "we" in line 175. This "we" is able to destroy "the sanctuary", a holy and sacred place used as a metaphor probably to refer to the human body, the temple of the soul or spirit according to the theories of Christianity. In a Freudian perspective, the expression "O fie, fie, fie!" can be seen as the Super-Ego speaking aloud its own voice like in a self-reproach. In addition, the "waste ground" mentioned above may represent those sexual desires and hidden impulses that belong to the Id whereas the use of "we" may be another attempt of the Ego to justify the immoral behaviour by making generalizations or by giving the idea of a common and shareable human condition.

The monologue culminates in lines 177 with a self-scrutiny, "What dost thou...Angelo?" This has a strong impact on the scene since the Deputy blames himself in a sort of realisation of his miserable behaviour, thus reinforcing the belief that he is the immoral and not the supposed tempter. According to another scholar (Cash, 2014), this is the part of the soliloquy in which the character reaches the total understanding of his culpability and frees Isabella from any responsibility of temptation. This self-awareness reflects the fact that the Ego and the Super-Ego have apparently reached a sort of peaceful agreement in which the tension of the psychological conflict is eventually abated. In lines 178-183, Angelo's internal debate then concentrates on male sexual wishes that are considered as "foully", thus dishonourable, and on the moral question of whether to release Claudio since sinners, "Thieves", and moral arbiters, "judges", are both transgressors. His desires are so strong that he wonders whether he is really in 
love with Isabella or it is just a creation of his fervid imagination (“...I dream on?"). As a matter of fact, doubts about morality continue to torment Angelo's conscience: the lines 183-187 are characterized by the character's attempt to move his immorality to an external entity, a "cunning enemy", that seems responsible of inducing him into temptation because a man can be easily and instinctively attracted by goodness. This attempt is an action that can eventually help him to cope with his personal distress since the Ego is not ready yet to fully accept its own responsibility in this matter and, hence, it is more tolerable to attribute the fault to external factors. This attribution is called, in psychoanalysis, projection since it represents a defense mechanism of the mind in which unbearable emotions and/or fantasies are removed from the individual and then displaced towards another person or situation (Rohleder, 2014). This mechanism used by the Ego is clearly unconscious.

The entity of the mental defenses adopted by Angelo is so intense that he is inclined towards a spiritual elevation of himself when he utters the words "saint" and "saints" as if he was a holy person. This attribution of sanctity is a comical effect that may underline the fact that Measure for Measure should be considered a comedy rather than a tragedy as stated by Dodds when he underlines the intensity and quality of the character's suffering. In fact, duplicity and ambivalence emerge in the words used by Shakespeare in lines 187-190 in which the "double vigour" can refer to Angelo's conscience since he is the one who is living a conflict between his "art", as a Deputy, and his "nature", as a human being. In a Freudian view, the "art" may be represented by the Ego because that part of the psyche that governs our life and deals with the external world, while "nature" clearly refers to the instinctual and biological impulses that strive continually to express themselves. The ending lines of the speech depict the character's superficial attitude towards love and have a final effect on the audience who is likely impressed by the possibility that, in the end, this man is expressing honest and true feelings of affection differently from the circumstances represented earlier in the same act. The words "once stir my temper" are significant here since "temper", synonym of personality, disposition, mood and mental state, may refer to the psychological conflict described so far.

\section{Conclusion}

In conclusion, this analysis confirms that the main theme of the play is morality, that there is no fair judgement of others' misconduct and that it is wiser to reflect on one's own behaviour. According to William Hazlitt (Leone, 2006), Shakespeare's talent was to highlight the true nature of his characters and, in particular, that it is good even in bad people. Actually, the Deputy is an undeniable example of a person who is in conflict with two extremes: an excess of puritanism on one side and a need for laxity on the other. Freud's theories of functioning of the mind give a significant contribution to the understanding of the psychological conflict that may occur in an individual when tormented by moral questions. Many examples of the conflicting interaction between the three parts 
of the human mind in relation to morality have been broadly described in this paper. Lastly, a final remark concerns the author's choice of the name Angelo for his character. This name recalls a Christian figure, an angel, asexual and morally pure, who is commonly known as a guardian with the role to protect and guide a person or a community. The association that Shakespeare makes between the name chosen for his character and its religious equivalent seems rather ironic in this play.

\section{Conflicts of Interest}

The author declares no conflicts of interest regarding the publication of this paper.

\section{References}

Cash, P. (2014). Measure for Measure. English Association Shakespeare Bookmarks Longer Commentaries Number 3 (15 p.).

https://englishassociation.ac.uk/wp-content/uploads/2020/12/2.14.7.3-Publications-Bo okmarks-Shakespeare-Bookmarks-Measure-for-Measure-by-Peter-Cash.pdf

Dodds, W. (1946). The Character of Angelo in "Measure for Measure". The Modern Language Review, 41, 246-255. https://www.jstor.org/stable/3717058 https://doi.org/10.2307/3717058

Freud, S. (1915). The Unconscious. In S. Freud (Ed.), General Psychological Theory Papers on Metapsychology (pp. 116-150). Macmillan Publishing Company.

https://www.sas.upenn.edu/ cavitch/pdf-library/Freud_Unconscious.pdf

Freud, S. (1923). The Ego and the Id. The Standard Edition of the Complete Psychological Works of Sigmund Freud, Volume XIX (1923-1925): The Ego and the Id and Other Works (pp. 1-66).

https://www.sas.upenn.edu/ cavitch/pdf-library/Freud_SE_Ego_Id_complete.pdf

Greenblatt, S. (1997). Measure for Measure. In The Norton Shakespeare Based on the Oxford Edition (pp. 2047-2048). W. W. Norton \& Company.

Leone, M. A. (2006). Shakespearean Morality in Measure for Measure. http://www2.cedarcrest.edu/academic/eng/lfletcher/measure/mleone.htm

Rohleder, P. (2014). Projection, Overview. In T. Teo (eds.), Encyclopedia of Critical Psychology. Springer. https://doi.org/10.1007/978-1-4614-5583-7_415

Vithoulkas, G., \& Muresanu, D. F. (2014). Conscience and Consciousness: A Definition. Journal of Medicine and Life, 7, 104-108.

https://www.ncbi.nlm.nih.gov/pmc/articles/PMC3956087/pdf/JMedLife-07-104.pdf 